Received 17.01.2018 Reviewed 11.04.2018 Accepted 20.04.2018

A - study design

B - data collection

C - statistical analysis

D - data interpretation

$\mathbf{E}$ - manuscript preparation

F - literature search

\section{Assessment of the impact of climate change on the freshwater availability of Kaduna River basin, Nigeria}

\author{
Gloria C. OKAFOR ${ }^{1) B C D}$, Kingsley N. OGBU ${ }^{2) A E F ~} \bowtie$
}

\footnotetext{
1) Kwame Nkrumah University of Science and Technology, Kumasi, Ghana; e-mail: gloriacokafor@yahoo.com

${ }^{2)}$ Nnamdi Azikiwe University, Faculty of Engineering, PMB 5025, Awka, Anambra State, Nigeria;

e-mail:kn.ogbu@unizik.edu.ng
}

For citation: Okafor G.C., Ogbu K.N. 2018. Assessment of the impact of climate change on the freshwater availability of Kaduna River basin, Nigeria. Journal of Water and Land Development. No. 38 p. 105-114. DOI: 10.2478/jwld-2018-0047.

\begin{abstract}
Changes in runoff trends have caused severe water shortages and ecological problems in agriculture and human well-being in Nigeria. Understanding the long-term (inter-annual to decadal) variations of water availability in river basins is paramount for water resources management and climate change adaptation. Climate change in Northern Nigeria could lead to change of the hydrological cycle and water availability. Moreover, the linkage between climatic changes and streamflow fluctuations is poorly documented in this area. Therefore, this study examined temporal trends in rainfall, temperature and runoff records of Kaduna River basin. Using appropriate statistical tools and participatory survey, trends in streamflow and their linkages with the climate indices were explored to determine their amplifying impacts on water availability and impacts on livelihoods downstream the basin. Analysis indicate variable rainfall trend with significant wet and dry periods. Unlike rainfall, temperature showed annual and seasonal scale statistically increasing trend. Runoff exhibit increasing tendency but only statistically significant on annual scale as investigated with Mann-Kendall trend test. Sen's estimator values stood in agreement with Mann-Kendall test for all variables. Kendall tau and partial correlation results revealed the influence of climatic variables on runoff. Based on the survey, some of the hydrological implications and current water stress conditions of these fluctuations for the downstream inhabitants were itemized. With increasing risk of climate change and demand for water, we therefore recommend developing adaptive measures in seasonal regime of water availability and future work on modelling of the diverse hydrological characteristics of the entire basin.
\end{abstract}

Key words: climate change, Mann-Kendall test, partial correlation, streamflow, water availability

\section{INTRODUCTION}

Water is an essential instrument of livelihood support. Though the quantities needed by human for drinking and sanitation purposes are relatively small, the basic satisfaction of these needs today is marred by access to quality and availability of water resources. Other several purposes most importantly irrigated agriculture, industrial uses and in particular hydropower uses require water in larger quantities. These activities critically depend on a sufficient amount of freshwater that can be withdrawn from rivers, lakes, and groundwater aquifers.

Scientific studies suggest that the changing world's climate have considerable effects on freshwater resources availability with amplifying impacts on livelihoods of people particularly in arid and semiarid areas such as Nigeria. Climate change caused by increasing concentration of greenhouse gases in the atmosphere and usually linked to increasing temperature and shifts in rainfall pattern [KUNDU et al. 2016], directly or indirectly affects the natural environment 
and results in hydrology alterations of watersheds [WoBUS et al. 2015]. Some of these changes including changes in flood or drought frequency, magnitude and seasonality of runoff [TRENBERTH 2008] can lead to reduction in available water resource. In the same way, availability of water or actual per-capita renewable water resources is on the decline influenced by climate factors and non-climatic stressors comprising pressures from rapidly growing population, urbanization, changes in land use, among others [EAKIN, LUERS 2006]. As a cross cutting issue, this will invariably affect variety of natural and anthropogenic processes; posing additional threat to sectors of energy, agriculture, water supply for domestic and other purposes. Together with expected global population growth, lifestyle changes and economic prosperity in the coming decades, water demand will increase with constraints in development and societal well-being in many countries [NAIMAN, DUDGEON 2011] and thus aggravate these problems.

Investigations on past and probable future changing climatic patterns and impacts have been undertaken or are on-going in West Africa [ЕКPOH, NSA 2011; IDOWU et al. 2011; ROUDIER et al. 2014. This impact on available water resources is greatly paid attention to in different parts of the world due to their strong influences on human and environmental wellbeing. Studies in Sub-Saharan Africa [NGORAN et al. 2015] and West Africa [OYEBANDE, ODUNUGA 2010], show deteriorating conditions of available water resources due to climate change with varied and wide-ranging consequences. Although information is available on climate impact on water resources in Nigeria [ADELALU 2012; OJO et al. 2004], relatively little efforts have so far been made to understand the potential of water resources adaptation despite being highly vulnerable. There is also evidence of contrasted responses by hydrological systems in the Nigerian basins.

In recent years the effect of climate change on runoff has become prominent [KUNDZEWICZ et al. 2008; ZUO et al. 2015]. Globally, the anticipated changes in runoff varied regionally, with water availability decreasing in some locations but increasing in others [KUNDZEWICZ et al. 2008; SCHEWE et al. 2014]. Studies in Kaduna River basin indicate an increase in the magnitude and frequency of flooding events and increase in runoff potential of aquifers [HARUNA et al. 2013]. Nonetheless, few attempts have been made to deal with the changing climate and their large-scale impacts on runoff. As a main component of the whole water resources system, runoff variability usually results with complicated non-linear and unpredictable characteristics.

Furthermore, previous impact studies in Nigeria focused on annual discharge, high surface runoff, response patterns of hydrological parameters and its resultant environmental vulnerabilities such as flooding [DIKE, NWACHUKWU 2003; GARBA et al. 2013; IFABIYI 2013]. However, what appears not to be adequately articulated in these studies is the implications of the impacts on freshwater availability, particularly within rural settings. Such an understanding is necessary for the design and implementation of measures to improve the resilience of rural inhabitants to the impacts of water stress from changing climate. Similarly, in order to respond adequately to climate change in water management adaptation and optimize water availability in relation to each other, a good understanding of the hydro-climatic linkages of the Kaduna River basin is required. To help address these gaps, this paper examined linkages between runoff and climatic variables as well as their impact on freshwater availability of the Kaduna River basin which provides water supply for its inhabitants. Likewise, the basin considered in this study play important role in the socio-economic development of the administrative areas, we therefore, went a step further by investigating how the variations in freshwater availability have impacted on livelihoods of households.

\section{STUDY AREA}

The study area is the Kaduna River basin located in central North Nigeria. Kaduna River, upon which the Shiroro dam is built, mainly for power supply to Nigeria and neighbouring countries is particularly vulnerable to climate variability impacts because of its dependence on rainfall and current high levels of water stress. The basin extends from latitudes $09^{\circ} 06^{\prime} 32.64^{\prime \prime} \mathrm{N}$ to $11^{\circ} 30^{\prime} 12.64^{\prime \prime} \mathrm{N}$, and longitudes 05'30'39.34'E to $07^{\circ} 04^{\prime} 44.34^{\prime \prime} \mathrm{E}$ (Fig. 1). The basin general climate has typical dry and wet periods which are strongly influenced by highly variable topographic structure and low relief. The area receives in general, annual rainfall of about $1504.91 \mathrm{~mm} \cdot \mathrm{yr}^{-1}$, with gradual increase from north to south and average annual temperature of $27.46^{\circ} \mathrm{C}$. On the average, 110 days in a year has over $0.1 \mathrm{~mm}$ rainfall occurring. The river is subject to great seasonal fluctuations depending on the main rainy period from June to September.

Kaduna River plays a critical role for downstream water supply as thousands of people in the upstream and downstream are reliant on the water availability. The mainstay and primary livelihood of the locals living within this basin is built around rain-fed and irrigated agriculture. Scarcity of fresh and portable water occurs in many rural areas within the basin especially in the dry season [IBBI, TIMOTHY 2012]. The decline in water quality is compounding the scarcity of water and changing patterns of rainfall and runoff as a result of climatic variations exacerbates this situation. Climatic and hydrological extremes such as floods and droughts hit the basin population severely and regularly. Variability in the climate system and hydrological processes in the basin adds new challenges in the management of water resources. Thus, the failure to predict as well as manage water quality and quantity and the associated impacts from climatic variability (including extreme events) will impose huge costs on the country economies. 


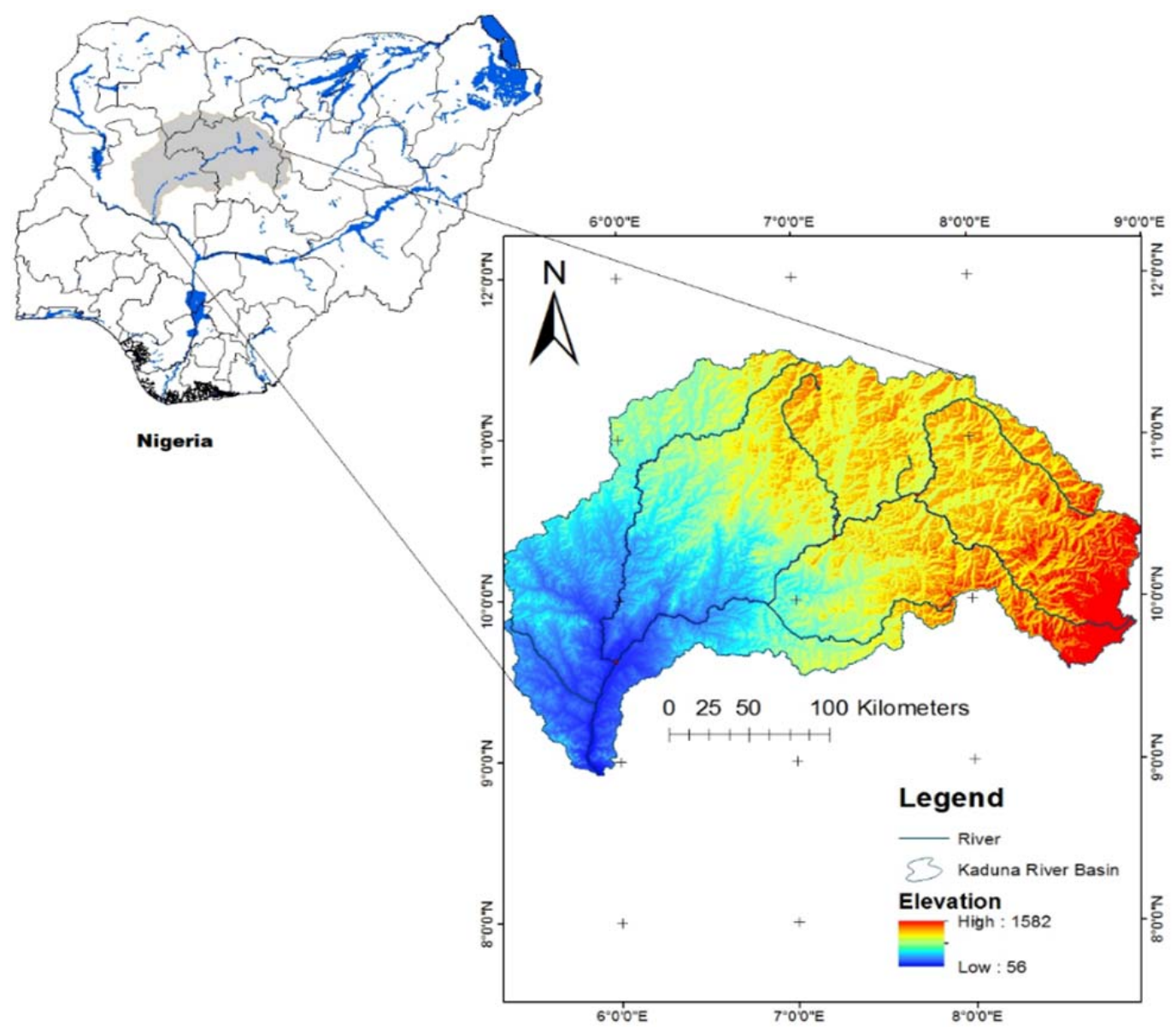

Fig. 1. Kaduna River basin; source: own elaboration

\section{METHODS}

In this study, we used series of daily mean temperature and rainfall datasets for the period 1975 to 2014 sourced from Nigerian Meteorological Agency (NIMET), Abuja. Similarly, runoff for the period 1990 to 2014 (available length of records) was provided by Shiroro Dam Hydro-Electric Power Station in Niger State. Mean annual, monthly and seasonal (April to October - rainy months; November to March - dry months) values for each hydro-climate variable were computed. Time series data were plotted to observe trends in data distribution and possibly, irregularities. Thereafter, the methods to determine serial correlation in the data series were observed [OKAFOR et al. 2017]. The non-parametric MannKendall (MK) test and Sen's slope estimator were employed to detect monotonic changes over time in the series. MK test have been used in earlier studies to detect trend in hydro-climatic datasets [Hu 2014; OKAFOR et al. 2017]. The Mann-Kendall statistic $\left(S_{m k}\right)$ [Kendall 1975; MANN 1945], theoretical calculation is shown in Equation (1).

$$
S_{m k}=\sum_{i=1}^{n} \sum_{j=i+1}^{n} \operatorname{sgn}\left(X_{j}-X_{i}\right)
$$

Where: $X_{j}$ and $X_{i}=$ the annual data values in year $j$ and year $i$, such that $j>i$ and where the sgn function is given as:

$$
\begin{gathered}
1 \text { if }\left(X_{j}-X_{i}\right)>0 \\
\operatorname{sgn}\left(X_{j}-X_{i}\right)=0 \text { if }\left(X_{j}-X_{i}\right)=0 \\
-1 \text { if }\left(X_{j}-X_{i}\right)<0 \\
\operatorname{Var}\left(S_{m k}\right)=\frac{N(N-1)(2 N+5)-\sum_{i=1}^{M} U_{i}(i)(i-1)(21+5)}{18}
\end{gathered}
$$

Under the null hypothesis of no trend and independence of the series term with the mean in which $M$ is the number of tied groups and $U_{t}$ denotes size of the $M^{\text {th }}$ group. The summation term in the numerator is used only if the data series contains tied values. It has been documented that for sample size $N \geq 10$, the statistic $S$ assumes normal distribution, the standard normal test statistic $Z_{s}$ is computed using

$$
Z_{S}= \begin{cases}\frac{S-1}{\sqrt{\operatorname{VAR}(S)}}, & \text { for } S>0 \\ 0, & \text { for } S=0 \\ \frac{S+1}{\sqrt{\operatorname{VAR}(S)}}, & \text { for } S<0\end{cases}
$$

In addition, Kendall tau and partial correlation were performed to determine if the trends in runoff are attributable to the changing climate. The partial correlation method, postulated by IMAN and HELTON [1988], allows us to examine the strength and direction of linear relationship between runoff and each climatic variable while controlling the influence of 
third variable. First, scatter plots were constructed between the variables to satisfy the assumptions of scale level, independent, linear relationship, normally distributed, and arranged in match pairs. The partial correlation coefficients $(P C C)$ that exist between $x$ and $y$ variable is ascertained by eliminating the effect of the $z$ variable, or other variables $z_{1}, z_{2}, \ldots$, are defined respectively as:

$$
\begin{gathered}
r_{y x z}=\frac{r_{y x z}-r_{y z} r_{x z}}{\left(1-r_{y z}^{2}\right)\left(1-r_{x z}^{2}\right)} \\
r_{y x z_{1} z_{2}}=\frac{r_{y x z_{1}}-r_{y z_{1} z_{2}} r_{x z_{1} z_{2}}}{\left(1-r_{y z_{1} z_{2}}^{2}\right)\left(1-r_{x z_{1} z_{2}}^{2}\right)}
\end{gathered}
$$

Where: $r_{y x z}=$ the simple correlation coefficients (SCC) between $y$ and $x, r_{y z}$ and $r_{x z}=$ the SCC between $y$ and $z$, and $x$ and $z$ respectively, and so on. The $S C C$ of $r_{y x}$ is defined as:

$$
r_{y x z_{1} z_{2}}=\frac{\sum_{i=1}^{n}\left(y_{i}-\bar{y}\right)\left(x_{i}-\bar{x}\right)}{\sqrt{\sum_{i=1}^{n}\left(y_{i}-\bar{y}\right)^{2}} \sqrt{\sum_{i=1}^{n}\left(x_{i}-\bar{x}\right)^{2}}}
$$

Where: $x_{i}$ and $y_{i}$ are respectively the time-series variables, $n$ is the span of variables $y_{i}$ and $x_{i}$. The partial correlation coefficient $(P C C)$ value range from a more significant positive correlation as it reaches +1 to a more significant negative correlation between two variables as it reaches -1 . The null hypothesis $\left(H_{0}\right)$ assumes that the $P C C$ between two variables is equal to zero.

The discussion on comparison of runoff (as an indicator of available water resources) and climate variables are limited to the corresponding time-slice available. Field visits were also made to the basin, focused group discussions with locals and face-toface interview with water users in three communities: Shiroro, Lavun and Gbako. This was to extract information on rainfall variability, temperature and runoff changes to determine impact on available surface water resources as well as vulnerability to water stress.

\section{RESULTS}

\section{ANNUAL CYCLE OF RAINFALL, RUNOFF AND TEMPERATURE TRENDS}

The mean yearly patterns of temperature, rainfall and runoff in the study area are shown in Figures $2 \mathrm{a}$, $2 \mathrm{~b}$ and Figure 3 respectively. Rainfall shows obvious oscillation and instability with annual mean above 65 $\mathrm{mm}$. The ten (10) years moving average indicates variation in rainfall totals giving dry and wet periods. Significant wet years can be seen in 1978 and 2008 while 1981 and 2011 as the driest years in the area. Wet years obviously bring the risk of flooding. The mean annual temperature pattern is increasing with maximum value of $28.87^{\circ} \mathrm{C}$ in 1987 followed by 1998. The monthly max (in July) and min (in January) temperature is $27.4^{\circ} \mathrm{C}$ and $19.49^{\circ} \mathrm{C}$, respectively. The variable minimal increasing pattern of mean annual runoff at Shiroro at the rate of $1.618 \mathrm{~m}^{3} \cdot \mathrm{yr}^{-1}$ is also observed. Significant peak periods can be seen in 1992, 2001 and 2012 years. While 2005 can be seen as the year with extreme minimum runoff $\left(164.12 \mathrm{~m}^{3}\right)$ in the area corresponding to decrease in rainfall and temperature at that time.
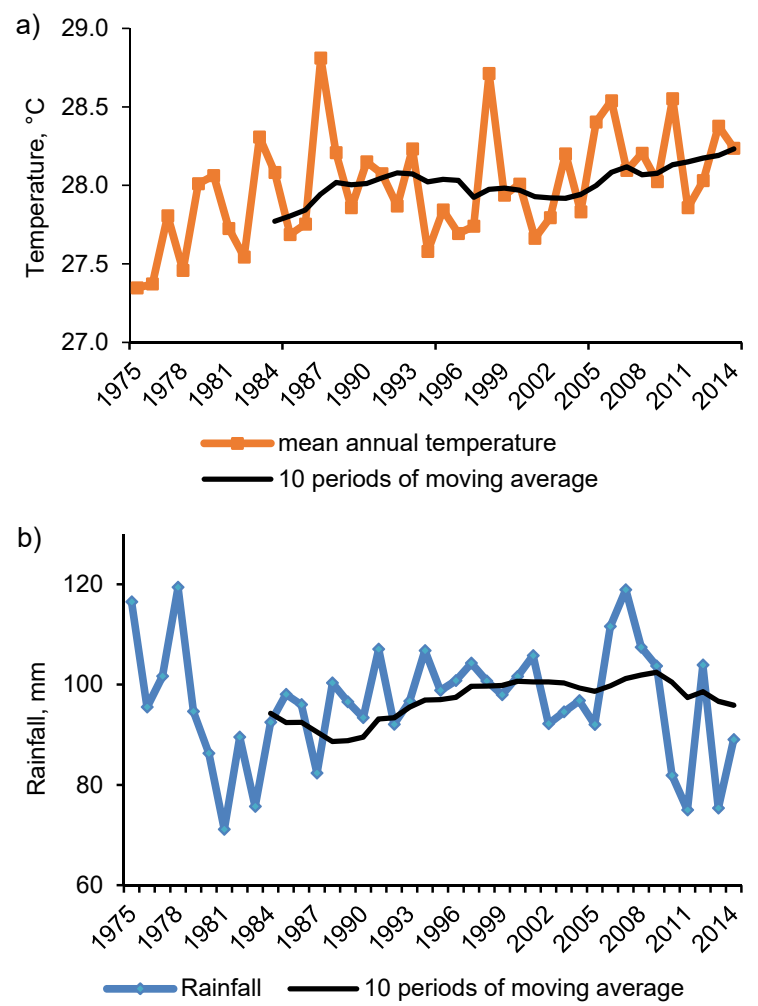

Fig. 2. Mean annual of climatic parameters for the study area: a) temperature; b) rainfall; source: own study

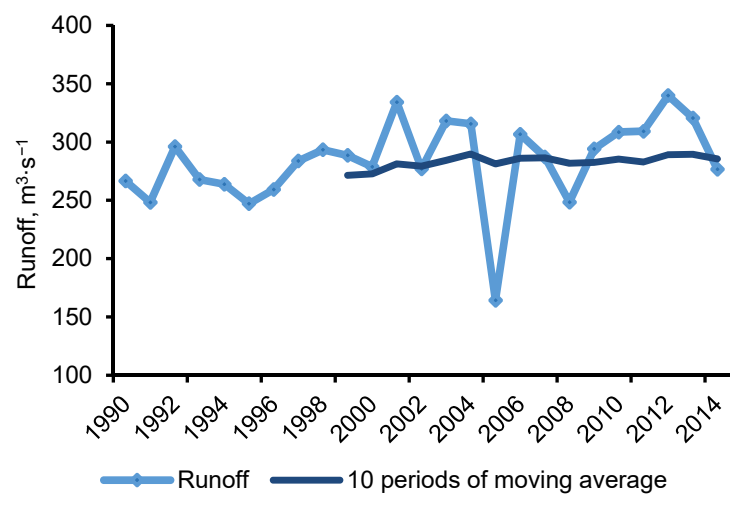

Fig. 3. Mean annual observed river runoff pattern at the outlet of Shiroro reservoir gauging station; source: own study

\section{SEASONAL CLIMATE TREND}

The seasonal trends are displayed in Figure 4. The rainfall data showed large disparities in average monthly patterns over downstream Kaduna River basin. There are distinct dry and rainy seasons which occurs for about five and seven months respectively. The maximum seasonal rainfall for the study period occurred in 1995-2004 decade with a value of 
a)

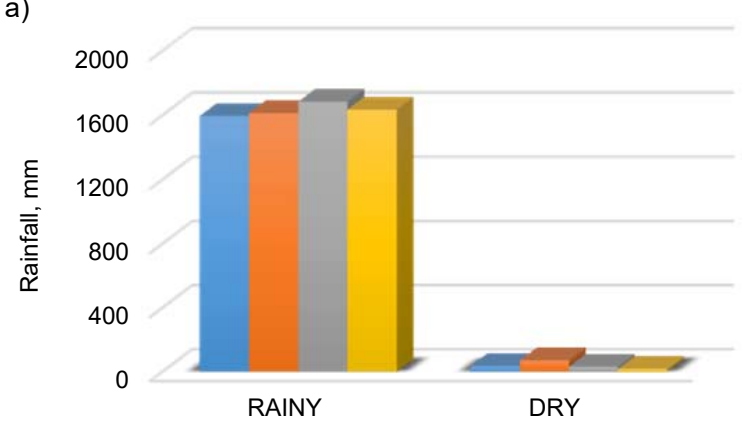

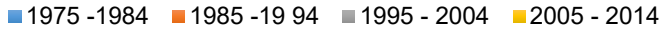
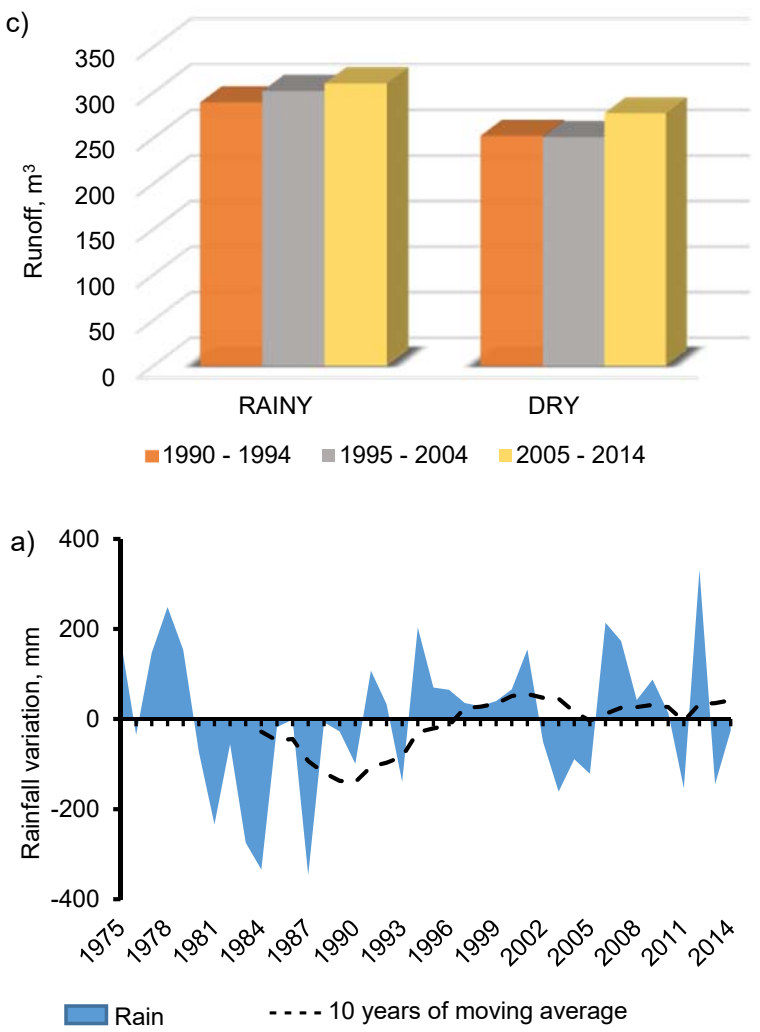

b)

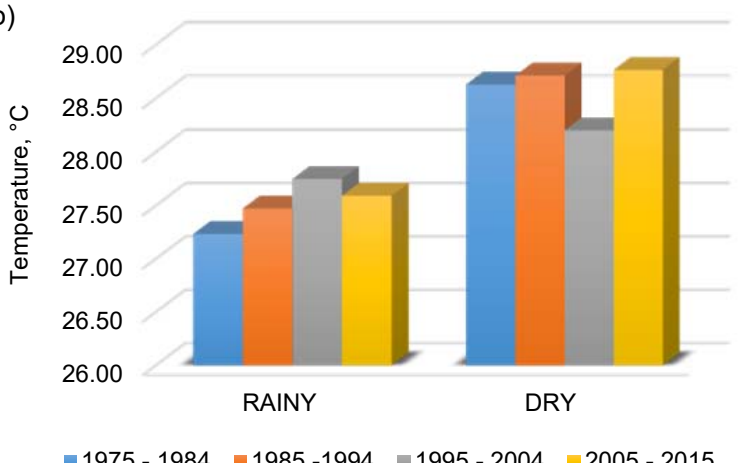

Fig. 4. Decadal means of: a) seasonal rainfall, b) temperature, c) runoff; source: own study

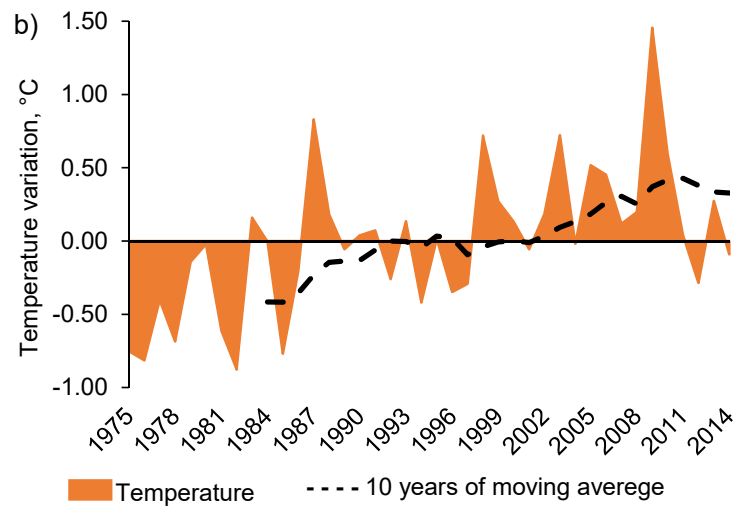

Fig. 5. The mean annual variations of climatic parameters and their mean differences of decadal values to the long-term mean at Minna station: a) rainfall, b) temperature; source: own study

$2556.95 \mathrm{~mm}$. When compared in decades, the results show that the dry season was varying especially in 2005-2014 decade (period when annual runoff was at lowest) and increasing in rainy season. Similarly, the mean seasonal runoff showed a relatively small increasing pattern with maximum seasonal mean value of $310.05 \mathrm{~m}^{3}$ in $2005-2014$ decade at Shiroro reservoir for the study period (1990-2014). The seasonal analysis of the mean temperature for the area also showed an increasing trend. Seasonal highest temperatures were observed in 1995-2004 (wet season) and 2005-2015 (dry season) decades.

\section{DECADAL VARIATIONS OF RAINFALL, TEMPERATURE AND STREAMFLOW RECORDS AS COMPARED WITH THE LONG-TERM MEAN (LM)}

In order to study the decadal variation of historical rainfall, temperature and runoff time series of the
Kaduna basin, the mean annual and seasonal values for the entire period of study (1975-2014) and for each decade (1975-1984, 1985-1994, 1995-2004 and 2005-2014) were computed and compared.

The long-term annual mean rainfall for Minna and Bida stations were $1204.90 \mathrm{~mm}$ and $1092.18 \mathrm{~mm}$. From Figure 5, it is observed that on both annual and seasonal basis; a wet period (1995-2004) period is observed over the area which has a mean annual rainfall of $15.80 \mathrm{~mm}$ higher than the long-term average and temperature over Minna are warmer than the long-term average. A dry period (1975-1984, 20052014) with mean annual rainfall of 29.58 and 2.37 lower than the long-term averages were also observed while the period (1975-1984) over Minna is cooler than the long-term average. The mean decadal changes for runoff are not remarkable but mostly increasing as shown in Figure 6. Annual mean runoff of 477.95 less than the long-term average (1990-1995) was ob- 
served also for the dry periods. The biggest variation in seasonal runoff was found for the period 20052014 which had a mean of $126.725 \mathrm{~m}^{3}$ less than the long-term average.

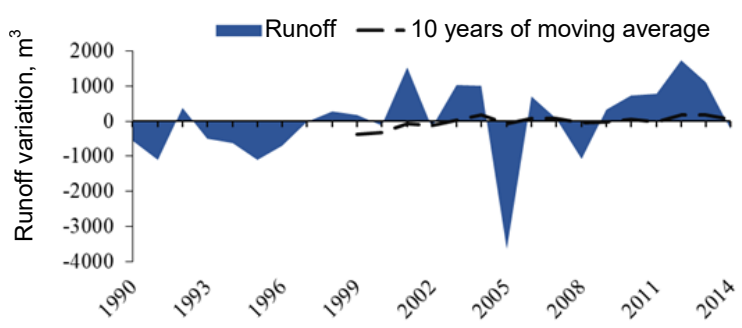

Fig. 6. The annual runoff differences with their decadal mean variances compared to the long-term mean $(L M)$ at Shiroro reservoir; source: own study

\section{DISCUSSION}

\section{SEASONAL CLIMATE ANALYSIS}

Rainfall is highly variable within local settings [NENWIINI, KABANDA, 2013] as revealed in the study with obvious decreasing trend in the 2005-2014 decade. The observed variability in seasonal rainfall in this study was in contrast with the study conducted by SUlEIMAN and IFABIYI [2014]. They found that variability is greater between the months of May to October of which coincides with the rainy season. Similar observations in irregular pattern of annual rainfall were made by EzE [2006]. The study suggests a slight increase in rainfall amount from irregular pattern over the Kaduna River catchment at Shiroro Local Government Area as indicated from the significant wet periods observed from this study. The warmest period occurred in 1985-1994 decade (similar to dry years in the 80's found in rainfall) but the coolest years were in 1974 and 1994. The results of the temperature analysis indicate increasing trend in annual mean temperature while decreasing high temperature events are pronounced in dry season than in rainy season. From the runoff result, increasing tendency has been observed which is supported by runoff analysis performed by FAN et al. [2011]. Equally, the frequency, amount and the duration of rainfall events determine the trend of hydrological events such as river runoff and flood. The observed significant wet years and slight increase in rainy season rainfall amount follows the flood events which occurred in the area at these years; 1998, 2003 and 2012 agreed with the works of EZE [2006] and ADAKAYI [2012]. These authors re- ported similarities in flood events and significant wet years. Both rainfall and runoff have strong inter-annual and intra-annual variabilities corroborating the work by OLADIPO [2008]. The variability in runoff is higher than that found in rainfall owing to annual runoff influence by both annual variability, amount of rainfall [PEEL et al. 2001] and other environmental characteristics.

\section{MANN-KENDALL (MK) TEST ANALYSIS}

The MK trend test for annual and seasonal series of runoff, rainfall and temperature are shown in Table 1. The test statistic $Z_{S}$ was used as measure of significance in the trend. On annual scale, no trend was detected in rainfall data in the catchment but showed statistically significant decreasing trend for seasonal analysis.

Temperature results indicated statistically increasing trends in both annual and seasonal scale. Overall increasing trend in runoff was observed for the period 1990-2014 as seen with Mann-Kendall test but statistically significant for annual scale. Sen's estimator values ranged from -0.41 to $2.14 \mathrm{~mm} \cdot \mathrm{yr}^{-1}$. This result points toward the presence of both increasing and decreasing trends (non-monotonic temporal pattern) in the time series.

\section{LINKAGES BETWEEN RUNOFF AND CLIMATE TRENDS - KENDALL TAU AND PARTIAL CORRELATION}

The interest of the relationship analysis is to determine if the trends in runoff are attributable to climate change and variability. Similar studies applied in other basins for linking runoff trends to climatic changes were reported by Hu [2014], ABDUL AZIZ and BURN [2006] and CHEN et al. 2007]. The potential relationships of the significant trends in hydrological variables were investigated through a correlation analysis with climatic variables. The Kendall tau for these series are calculated and runoff $(0.33)$ is more significantly correlated with rainfall $($ tau $=0.280)$ than with temperature $(\mathrm{tau}=0.047)$ at $95 \%$ confidence level. The positive relationships between these variables are apparent from the trend series as shown in Figure $2 \mathrm{a}$ and $2 \mathrm{~b}$. The partial correlation analysis between climatic variables and runoff performed at a confidence level of $95 \%$ to test if the correlation was significant. The seasonal and annual partial correlation coefficient $P C C$ between runoff and climatic variables (rainfall and mean temperature) during the

Table 1. Statistical trend test results for the rainfall, temperature and runoff series at Minna station

\begin{tabular}{|c|c|c|c|c|c|c|c|c|c|}
\hline \multirow{2}{*}{ Statistical test } & \multicolumn{3}{|c|}{ Rainfall } & \multicolumn{3}{|c|}{ Temperature } & \multicolumn{3}{|c|}{ Runoff } \\
\hline & annual & rainy & dry & annual & rainy & dry & annual & rainy & dry \\
\hline$Z_{S}$ & 0.41 & 0.69 & $-2.71 *$ & $3.53 *$ & $2.04 *$ & $4.24 *$ & $2.31 *$ & 1.75 & 1.80 \\
\hline$p$-value & 0.68 & 0.49 & $0.01 *$ & $0.00 *$ & $0.04 *$ & $0.0001^{*}$ & $0.02 *$ & 0.08 & 0.07 \\
\hline Qmed & 0.95 & 2.15 & -0.41 & 0.02 & 0.02 & 0.02 & 2.14 & 2.06 & 1.68 \\
\hline
\end{tabular}

$Z_{S}:=$ Mann-Kendall trend test, $p$-value $=95 \%$ confidence level, $Q_{\mathrm{med}}=$ Sen's slope estimator, $*=$ significant trend $(\alpha=0.05)$. Source: own study. 
period from 1990 to 2014 indicates that the runoff is influenced by both precipitation and temperature. All of the relationships between runoff and climatic variables on annual and seasonal timescale show weak relationship $(P C C=0.151,-0.215)$, while the seasonal analysis exhibit negative correlation. Runoff shows the closest relationship with rainfall. It can be concluded from the partial correlation analysis that the runoff is supplied and highly controlled by precipitation rather than temperature. Over the period 1990 2014 , the strong positive correlation between pattern of annual rainfall and surface runoff was also observed at Shiroro dam by SULEIMAN and IFABIYI [2014]. Therefore, increasing (positive values) rainfall could be associated with increasing annual flow. The study findings however, coincide with the study conducted by EzE [2006]. He noted that a slight increase in rainfall increases the amount of river runoff and runoff of flood into the Shiroro reservoir over the period 1981-2003.

\section{HYDROLOGIC IMPACTS OF METEOROLOGICAL CHANGES AND DOWNSTREAM KADUNA RIVER - CURRENT WATER STRESS CONDITIONS}

Overall, there is large intra-annual variation of the rainfall between 1975 and 2014. Rainfall variability can be related to the movement of the inter-tropical convergence zone (ITCZ) as controlled by the monsoon trade winds movement. The stable increases in temperature observed are consistent with increasing temperatures over Africa since 1960s. The warming observed across the globe is evident in warmer and dry period characterizing the recent decade (20052014) in the catchment. The intra-annual variabilities of these hydro-climatic variables play a key role in determining the characteristics of a given climate. The correlation analysis in has suggested a dominant role of rainfall in runoff generation over the basin. However, the overall varying rainfall trend over the study period was accompanied by long-term increasing trend in runoff. This result may imply that other factors also affect flow variations such as land-use changes, groundwater recharge and other biophysical factors. Meanwhile the increase in temperature leads to the declining runoff in the dry periods (high evaporation). The results have proven that the river's natural flow (surface runoff) is very sensitive to rainfall variations and temperature changes.

Furthermore, rainfall has ample impacts on river levels and runoffs, while increases in temperature have been found to affect the rates of evaporation and evapotranspiration, reducing the amount of surface water, thus influencing water balance of a basin. In cases when intense rainfall does occur, high rates of surface runoff may contribute to flash floods and limit the capacity of land and soils to regulate water supplies more evenly. From the interviews, the inhabitants noted erratic rainfall and flood events which destroys crops and runs-off. They also could no longer tell the timely onset of the rain preventing crops to be planted early. The assessment indicated that $76.5 \%$, $46.3 \%$ and $68.8 \%$ proportion of the households in Shiroro, Gbako and Lavun have experienced water stress respectively. These are owing to population pressure, failure and drying up of streams, wells and boreholes, they noted. Additionally, water available for domestic activities such as cooking, bathing and drinking water for both human and livestock are reduced. Water scarcity during the dry season gave rise to lowering soil moisture levels. This in combination with high temperature develops hard soil layer that limit infiltration especially in areas with poor vegetation cover or high rates of surface water evaporation. Also, temperature increases might shorten the cropgrowing period and reduces the amount of biomass that accumulates [CERVIGNI et al. (eds) 2013]. This suppresses crop yields even if crops are not stressed by water conditions.

Increase in temperature resulted in intense heat waves, most of the water scarcity and drought cases reported, that could be challenging for water resources management and agricultural dependent vulnerable populations. Equally, increasing flood events that lead to soil erosion and washed away their farmlands especially those close to the river bodies were of concern to them.

Water scarcity (not in an absolute sense but significant reduction levels) still exist in the basin especially during the dry season due to variability in rainfall and increase in evapotranspiration (high temperature) despite few seasonal available public water sources such as a solar powered borehole, three hand pumps at the study location. Increasing population observed from larger family size plays a major role in this increase in water scarcity because it reduces percapita availability even with unchanged resources. The increasingly irregular availability of water threatens the livelihoods of households and smallholder farmers. The changes in rainfall and runoff described are likely to have significant effects on the reliability of hydropower and irrigation systems, which are a function of both average magnitude and variability of inflows. Increases may entail adverse impacts such as increasing flood risk, deteriorating water quality, and malfunctioning of water-related infrastructure. If the observed varying trend in rainfall continues in the future (as also predicted by models), this could affect the sustainability of surface water resources and groundwater recharge.

\section{CONCLUSIONS}

In the wake of reducing current vulnerability of communities to climate variability and extreme events as well as improving management options to deal with the worst-case scenarios and also take advantage of opportunities that may arise, this study assessed the linkages between the changing climate and runoff in the downstream Kaduna River basin as follows. First, the temporal trends of runoff, rainfall, and tempera- 
ture on annual and decadal basis during the period of 1975-2015 were analysed. The statistical significance of these trends was investigated using the MannKendall (MK) test. Afterwards, using Kendal tau and the partial correlation method, the correlation between runoff and climatic variables were characterized in a seasonal and yearly scale.

We found no clear trend in rainfall but significant wet and dry periods both on seasonal and annual scale. For temperature data, the test indicates a significant upward trend especially in recent decade (20052014). Runoff results obtained showed overall increasing trend that is non-statistically significant. The correlation analysis indicates runoff generation over the basin is influenced by both climate variables but highly controlled by precipitation rather than temperature. Site visits and survey further confirmed and revealed some hydrological implications of both increasing and decreasing temporal trends in the hydroclimatic variables.

The observed increases in temperature with varying rainfall trend lead to water stress which impacted on livelihood. Even though the research independently analysed climate impact on runoff and did not account for tipping points in natural processes or consider human activities, major indicators of seasonal water stress and flooding in the study area were identified, which supports the locals expressed perceived effects of climate variability. Based on the results obtained, it can be concluded that there is existence of climate variability due to variations in rainfall, temperature and runoff data obtained from the basin. The result was negative impact on local ecosystem and water availability, hence, well-being of residents in the area. The positive or increasing runoff can be harnessed during the rainy season to reduce flood risk and use during the scarcity periods. With potential future changes in climate and hydrological regimes of the river basin, it is necessary to develop adaptive measures in seasonal regime of water availability such as rainwater harvesting for different purposes and related economic sectors. Finally, future work should be carried out to model the effect of climate change on hydrological events not only runoff, and diverse hydrological characteristics of the entire basin to reveal the response mechanism of hydrological factors to potential climate change and determine their role in the basin hydropower water management.

\section{Acknowledgments}

This study was sponsored by West African Science Service Centre on Climate Change and Adapted Landuse (WASCAL). The authors thank Shiroro Hydro-electrical Power Station, Minna and Nigerian Meteorological (NIMET) Agency, Abuja who provided the hydrological and climatic data respectively.

\section{REFERENCES}

ABDUl AzIz O.I., BuRN D.H. 2006. Trends and variability in the hydrological regime of the Mackenzie River Ba- sin. Journal of Hydrology. Vol. 319 (1-4) p. 282-294. DOI 10.1016/j.jhydrol.2005.06.039.

ADAKAYI P.E. 2012. An assessment of the rainfall and temperature variations in parts of Northern Nigeria. Jos. University of Jos. PhD Thesis pp. 198.

Adelalu G.T. 2012. Climate variability and River Benue Discharge in Jimeta, Yola Area, Nigeria. Hydrology for Disaster Management (Special Publication of the Nigerian Association of Hydrological Sciences) p. 375-382.

Cervigni R., Valentini R., SAntini M. (eds) 2013. Toward climate-resilient development in Nigeria. Washington, D.C. World Bank Publications. ISBN 978-0-8213-99231 pp. 212. DOI 10.1596/978-0-8213-9923-1.

Chen H., Guo S., Xu C. Singh V.P. 2007. Historical temporal trends of hydro-climatic variables and runoff response to climate variability and their relevance in water resource management in the Hanjiang basin. Journal of Hydrology. Vol. 344. Iss. 3-4 p. 171-184. DOI 10.1016/j.jhydrol.2007.06.034

Dike B.U., NwachuKwU B.A. 2003. Analysis of Nigerian hydrometeorological data. Nigerian Journal of Technology. Vol. 22. Iss. 1 p. 29-38.

EAKIN H., LUERS A.L. 2006. Assessing the vulnerability of social environmental systems. Annual Review of Environment and Resources. Vol. 31 p. 365-394 DOI 10.1146/annurev.energy.30.050504.144352.

ЕКРОH I.J., NsA E. 2011. Extreme climatic variability in North-Western Nigeria: An analysis of rainfall trends and patterns. Journal of Geography and Geology. Vol. 3. Iss. 1 p. 51-62. DOI 10.5539/jgg.v3n1p51.

EZE J.N. 2006. Vulnerability and adaptation to climate variability and extremes: A case study of flooding in Niger State, Nigeria. MSc. Thesis. Johannesburg, South Africa. University of the Witwa-tersrand.

FAN Y., Chen Y., Li W., WANG H., Li X. 2011. Impacts of temperature and precipitation on runoff in the Tarim River during the past 50 years. Journal of Arid Land. Vol. 3. Iss. 3 p. 220-230. DOI 10.3724/SP.J.1227.2011. 00220

Garba H., Ibrahim A., Ahmed S., Faustinus B. 2013. Hydrological modeling of the impact of climate change on a tropical perennial river flooding. Research Inventy: International Journal of Engineering and Science. Vol. 3. Iss. 6 p. $30-35$.

Haruna G., Abubakar I., Rabia L. B., Saminu A., AbdulLAHI I., FAUSTINUS B. 2013. Open Journal of Modern Hydrology. Vol. 3 p. 115-121. DOI 10.4236/ojmh. 2013.33015.

Hu Y. 2014. Water tower of the Yellow River in a changing climate: Toward an integrated assessment [online]. Delft, The Netherlands. UNESCO-IHE Institute for Water Education. PhD Thesis. ISBN 978-1-138-02714-5. pp. 112. [Access 12.10.2017]. Available at: http://repository.tudelft.nl/assets/uuid:f53620b8-3ce54f4b-9b48-a27d8c0496d5/2014 UNESCOIHE PHD Thesis YURONG $\bar{H} U . p d f$

IBBi S., TIMOTHY N. 2012. Water security and good governance in Niger State of Nigeria: Challenge for sustainable development. Transnational Journal of Science and Technology. Vol. 2. Iss. 8 p. 68-78.

Idowu A.A., Ayoola S.O., Opele A.I., Ikenweiwe N.B. 2011. Impact of climate change in Nigeria. Iranica Journal of Energy \& Environment. Vol. 2. Iss. 2 p. 145-152.

IFABIYI I.P. 2013. A rank-reduced analysis of runoff components and their response patterns to basin parameters in the northern basement complex, Nigeria. Civil and Environmental Research. Vol. 3. Iss. 7 p. 11-19. 
IMAN R.L., Helton J.C. 1988. An investigation of uncertainty and sensitivity analysis techniques for computer models. Risk Analysis. Vol. 8. Iss. 1 p. 71-90. DOI 10.1111/j.1539-6924.1988.tb01155.x

Kendall M.G. 1975. Rank correlation methods. 4th ed. Charles Griffin, London, U.K. ISBN 0852641990 pp. 202.

Kundu S., Khare D., Mondal A. 2016. Future changes in rainfall, temperature and reference evapotranspiration in the central India by Least Square Support Vector Machine. Geoscience Frontiers. Vol. 8. Iss. 3 p. 1-14. DOI 10.1016/j.gsf.2016.06.002.

Kundzewicz Z.W., Mata L.J., Arnell N.W., Döll P., JimeneZ B., OKI T., ShikLOMANOV I. 2008. The implications of projected climate change for freshwater resources and their management resources and their management. Hydrological Sciences Journal. Vol. 53. Iss. 1 p. 3-10. DOI 10.1623/hysj.53.1.3.

MANN H.B. 1945. Nonparametric tests against trend. Mann Source: Econometrica. Vol. 13. Iss. 3 p. 245-259. DOI 10.1017/CBO9781107415324.004.

NAiman R.J., Dudgeon D. 2011. Global alteration of freshwaters: influences on human and environmental well-being. Ecological Research. Vol. 26. Iss. 5 p. 865873. DOI $10.1007 / \mathrm{s} 11284-010-0693-3$.

NenwiIn S., KaBAndA T.A. 2013. Trends and variability assessment of rainfall in Vhembe South Africa [online]. Journal of Human Ecolology. Vol. 42. Iss. 2 p. 171176. [Access 12.10.2017]. Available at: http://www. krepublishers.com/02-Journals/JHE/JHE-42-0-000-13Web/JHE-42-2-000-13-Abst-PDF/JHE-42-2-171-132366-Kabanda-T-A/JHE-42-2-171-13-2366-KabandaT-A-Tx\%5B9\%5D.pmd.pdf

Ngoran S. D., Dogah K. E., Xue X. 2015. Assessing the Impacts of climate change on water resources: The SubSaharan Africa perspective. Journal of Economics and Sustainable Development. Vol. 6. Iss. 1 p. 185-194.

Ojo O., GBuyiro S. O., OKOlOye C.U. 2004. Implications of climatic variability and climate change for water resources availability and management in West Africa. GeoJournal. Vol. 61. Iss. 2 p. 111-119. DOI 10.1007/ s10708-004-2863-8
OKAFOR G.C., JiMOH O.D., LARBI K.I. 2017. Detecting changes in hydro-climatic variables during the last four decades (1975-2014) on downstream Kaduna River Catchment, Nigeria. Atmospheric and Climate Sciences. Vol. 7. Iss. 2 p. 161-175. DOI 10.4236/acs.2017.72012.

OlADIPO E. 2008. Climate change and sustainable livelihoods - the greening options. Paper presented at the First National Summit on the Environment, Abuja Nigeria.

Oyebande L., Odunuga S. 2010. Climate change impact on water resources at the transboundary level in West Africa: The cases of the Senegal, Niger and Volta Basins. The Open Hydrology Journal. Vol. 9 p. 163-172. DOI 10.2174/1874378101004010163.

Roudier P., Ducharne A., Feyen L. 2014. Climate change impacts on runoff in West Africa: A review. Hydrology and Earth System Sciences, European Geosciences Union. Vol. 18. Iss. 7 p. 2789-2801. DOI 10.5194/hess-182789-2014

Schewe J., Heinke J., Gerten D., Haddeland I., Arnell N.W., Clark D.B., Kabat P. 2014. Multimodel assessment of water scarcity under climate change. Proceedings of the National Academy of Sciences of the United States of America. Vol. 111. No. 9 p. 32453250. DOI 10.1073/pnas.1222460110.

SulEIMAN Y. M., IfABIYI I. 2014. The role of rainfall variability in reservoir storage management at Shiroro. International Journal of Science and Technology Bahir Dar, Ethiopia. Vol. 7. Iss. 1 p. 55-63.

TRENBERTH K.E. 2008. The impact of climate change and variability on heavy precipitation, floods and droughts. Encyclopedia of Hydrological Sciences. Vol. 2(11) p. 1-17.

Wobus C., Prucha R., Albert D., Woll C., Loinaz M., JONES R. 2015. Hydrologic alterations from climate change inform assessment of ecological risk to pacific salmon in Bristol Bay, Alaska. PLOS ONE. Vol. 10. Iss. $12 \mathrm{e} 0147242$. DOI 10.1371/journal.pone. 0143905.

Zuo D., Xu Z., Zhao J., ABbaspour K.C., YANG H., ZuO D., YANG H. 2015. Response of runoff to climate change in the Wei River basin, China. Hydrological Sciences Journal. Vol. 60. Iss. 3 p. 508-522. DOI 10.1080/ 02626667.2014 .943668 .

\section{Gloria C. OKAFOR, Kingsley N. OGBU}

\section{Ocena wpływu zmian klimatycznych na dostępność wody w basenie rzeki Kaduna, Nigeria}

\section{STRESZCZENIE}

Zmiany w prawidłowościach odpływu spowodowały poważne ograniczenia w dostępności wody, problemy ekologiczne w rolnictwie oraz zmiany warunków życia ludzi w Nigerii. Zrozumienie długoterminowej zmienności (w poszczególnych latach i dziesięcioleciach) dostępności wody w basenie rzeki jest ogromnie ważne w zarządzaniu zasobami wodnymi i adaptacji do zmian klimatycznych. Zmiany klimatu w północnej Nigerii mogą doprowadzić do zmian cyklu hydrologicznego i dostępności wody. Ponadto, związki między zmianami klimatu a zmiennym odpływem wody są dla tego obszaru słabo udokumentowane. $Z$ tego powodu $\mathrm{w}$ przedstawionych badaniach analizowano czasowe zmiany opadu, temperatury i odpływu wody z basenu rzeki Kaduna. Stosując odpowiednie narzędzia statystyczne i badania ankietowe, badano trendy przepływu wody i ich związki ze wskaźnikami klimatycznymi, aby udokumentować ich rosnący wpływ na dostępność wody i warunki życia mieszkańców w dolnym biegu rzeki. Analiza wykazała zmienność opadów z wyraźnymi okresami suchymi i wilgotnymi. W przeciwieństwie do opadów temperatura cechowała się statystycznie istotnym trendem rosną- 
cym w skali pór roku i lat. Odpływ wykazywał istotną statystycznie rosnącą tendencję tylko w skali roku, co wykazano testem trendu Manna-Kendalla. Wartości estymatora Sena były zgodne z wartościami uzyskanymi z zastosowaniem testu Manna-Kendalla dla wszystkich zmiennych. Wartości tau Kendalla i korelacje cząstkowe wykazały wpływ zmian klimatu na odpływ wody. Na podstawie badań ankietowych wykazano pewne skutki hydrologiczne i aktualne warunki stresu wodnego dla mieszkańców zamieszkujących tereny w dolnym biegu rzeki. Wobec rosnącego ryzyka zmian klimatycznych i zapotrzebowania na wodę zaleca się rozwijanie środków przystosowawczych do sezonowego reżimu dostępności wody i przyszłe prace poświęcone modelowaniu zmiennych cech hydrologicznych całego basenu.

Slowa kluczowe: dostępność wody, korelacje czastkowe, przeptyw wody, test Manna-Kendalla, zmiany klimatyczne 